\title{
Dietary Conjugated Linoleic Acid and Hepatic Steatosis: Species-Specific Effects on Liver and Adipose Lipid Metabolism and Gene Expression
}

\author{
Diwakar Vyas, ${ }^{1}$ Anil Kumar G. Kadegowda, ${ }^{2}$ and Richard A. Erdman' \\ ${ }^{1}$ Department of Animal and Avian Sciences, University of Maryland, College Park, MD 20742, USA \\ ${ }^{2}$ Department of Animal and Veterinary Sciences, Clemson University, Clemson, SC 29634, USA
}

Correspondence should be addressed to Diwakar Vyas, dvyas@umd.edu

Received 15 May 2011; Accepted 22 June 2011

Academic Editor: Konstantinos Kantartzis

Copyright ( 2012 Diwakar Vyas et al. This is an open access article distributed under the Creative Commons Attribution License, which permits unrestricted use, distribution, and reproduction in any medium, provided the original work is properly cited.

\begin{abstract}
Objective. To summarize the recent studies on effect of conjugated linoleic acid (CLA) on hepatic steatosis and hepatic and adipose lipid metabolism highlighting the potential regulatory mechanisms. Methods. Sixty-four published experiments were summarized in which trans-10, cis-12 CLA was fed either alone or in combination with other CLA isomers to mice, rats, hamsters, and humans were compared. Summary and Conclusions. Dietary trans-10, cis-12 CLA induces a severe hepatic steatosis in mice with a more muted response in other species. Regardless of species, when hepatic steatosis was present, a concurrent decrease in body adiposity was observed, suggesting that hepatic lipid accumulation is a result of uptake of mobilized fatty acids (FA) from adipose tissue and the liver's inability to sufficiently increase FA oxidation and export of synthesized triglycerides. The potential role of liver FA composition, insulin secretion and sensitivity, adipokine, and inflammatory responses are discussed as potential mechanisms behind CLA-induced hepatic steatosis.
\end{abstract}

\section{Introduction}

Obesity is a chronic metabolic nutritional disorder that has increased at an alarming rate in the last 20 years [1]. In the US, $68 \%$ of the adults (age $\geq 20$ years) and $18 \%$ of children (2-19 years) are either obese or overweight as per the National Health and Nutrition Examination Survey $[2,3]$. Incidence of obesity is associated with many health complications such as hypertension, hyperlipidemia, cardiovascular disease, type 2 diabetes [4], and a range of lipid abnormalities, the most common being nonalcoholic fatty liver disease (NAFLD) [4].

NAFLD is an important health concern due to its high prevalence ( $\sim 20 \%$ of adult population) and its association with insulin resistance and metabolic syndrome [5]. It is characterized by hepatic lipid accumulation primarily in the form of triglycerides (TG) [6]. Some of the potential steps involved in the progression of NAFLD may involve increased uptake of circulating fatty acids (FA) [7], increased hepatic denovo lipogenesis (DNL) [8], reduced rate of FA oxidation [9], or reduced FA secretion $[10,11]$. When
NAFLD is associated with inflammation and fibrosis, it is termed as nonalcoholic steatohepatitis (NASH), a serious condition that could lead to liver cirrhosis, hepatic carcinoma, and liver failure [12]. The pathogenesis of NAFLD can be explained by "two hit" hypothesis suggesting steatosis as the "first hit" which increases the vulnerability of liver to various second hits like oxidative stress and inflammation leading to NASH [13].

Although no specific guidelines exist for treatment of NAFLD, recommendations are aimed at reducing body weight due to its strong association with obesity and metabolic syndrome [4]. In this regard, bioactive lipids/FA as functional food may be important in modulating metabolism and body weight. A specific group of polyunsaturated FA collectively known as conjugated linoleic acid (CLA) have been suggested to have an effect on regulating energy metabolism [14] and is being used commercially as a weight-loss supplement. CLA were recently granted "Generally Recognized As Safe", status in the United States (GRN no. 232; http://www.cfsan.fda.gov/) for use as a dietary 
supplement. However, CLA effects are varied depending on the type of CLA isomer, the animal's physiological condition, and the tissue type examined. In this paper, we summarize the recent studies on effect of CLA on hepatic lipid metabolism highlighting the potential regulatory mechanisms.

\section{Conjugated Linoleic Acid}

Conjugated linoleic acid refers to a group of dienoic derivatives of linoleic acid with conjugated double bonds arranged in different combinations of cis and trans configuration [15]. Currently, 16 naturally occurring CLA isomers have been identified with different positional $(7 / 9,8 / 10,9 / 11,10 / 12$, and 11/13) and geometric (cis/cis, trans/trans, cis/trans, and trans/cis) combinations $[16,17]$.

Sources of CLA include those naturally present in dairy products and meat from ruminant animals or those contained in industrially hydrogenated vegetable oils and other synthetic products [14]. The CLA originating from the ruminant products predominantly consist of cis-9, trans11 CLA $(>80 \%)$, with a small amounts of trans-10, cis-12 CLA and other isomers [18]. The industrially synthesized CLA and other commercial products intended for human consumption typically consists of equal amounts of cis-9, trans-11 CLA and trans-10, cis-12 CLA and other isomers [19]. Of all the CLA isomers, cis-9, trans-11 CLA and trans10, cis-12 CLA have been the most widely studied due to their biologically active properties [15].

\section{Physiological Effects of CLA}

A great deal of current interest in CLA is due to their bioactive properties including anticarcinogenic [19], antiatherogenic [20], immunity enhancing [21], and effects on body composition [22]. Each CLA isomer has unique bioactive properties, and hence, the biological effect from a mixture of dietary CLA isomers, as is the case in most of the studies, would be the combined effect of their distinct isomers [15]. For example, cis-9, trans-11 CLA and trans-10, cis-12 CLA have additive effects on cancer [23] and immune cell functions [24] but are antagonistic on insulin sensitivity. While cis-9, trans-11 CLA improves insulin sensitivity, trans10, cis-12 CLA causes insulin resistance. Also, trans-10, cis-12 CLA is solely responsible for changes in body composition and reducing adipose mass [25].

3.1. Body Weight and Lean Mass. CLA reduces body weight and body fat mass and increases lean mass in different species [22]. However, the response appears to vary depending on species, physiological stage, and fat depot $[22,26]$. Table 1 provides a summary of studies reviewed across species with respect to body weight and adiposity, where the number of experiments showing significant $(P>0.05)$ increases, decreases, or no change and the mean response to dietary trans-10, cis-12 CLA within those categories are reported. The range of trans-10, cis-12 CLA addition in these studies varied between 0.1 and 1 percent of the diet.
Trans-10, cis-12 CLA reduces body fat to a maximum extent in mice $(60 \%$ to $80 \%)[27,28]$. However, modest and inconsistent effects are seen in rats $[49,82]$, hamsters (9\% to 58\%) [54, 55], and pigs (6\% to 25\%) [83]. Similarly, variable responsiveness to CLA was observed for epididymal, perirenal, and subcutaneous body fat depots [55]. Inconsistent responses to trans-10, cis-12 CLA have been reported in clinical trials with humans [84]. Some have shown significant effects on body composition [63, 85], while others have not $[64,65]$. The differences in the responses are attributed to differences in the dose levels, age, and rate of adipose tissue TG turnover [14, 66, 84]. The response to CLA isomers also depends on the physiological state of the animal which is probably due to differences in the preferential uptake of CLA by different tissues. For example, trans-10, cis-12 CLA is preferentially taken up by the mammary tissue during lactation leading to substantial $(\sim 45 \%)$ decrease in milk lipid synthesis [29].

3.2. Effects of CLA on Hepatic Lipid Metabolism. Liver plays an important role in energy homeostasis, as it converts excessive dietary glucose into FA which is exported as TG. Liver is an important target for CLA effects irrespective of the physiological condition. Of the different CLA isomers, trans10, cis-12 CLA causes increased lipid accumulation leading to hepatic steatosis $[30-32,86]$. However, the intensity of lipid accumulation varies depending on the level of CLA in the diet, duration of feeding, physiological condition, and animal species (Table 1). The factors leading to hepatic lipid accumulation are multifactorial involving increased FA influx, increased FA synthesis, and altered FA oxidation and TG secretion insufficient to prevent lipid accumulation (Figure 1) [33]. These mechanisms are probably not mutually exclusive and could act in a coordinated manner to hasten the development and progression of fatty liver [87].

3.2.1. Hepatic FA Synthesis. Under normal conditions, de novo lipogenesis contributes minimally to the lipid pool in the liver [88]. However, the lipid synthesis increases to as much as $26 \%$ during steatotic conditions [89]. The increase in hepatic lipid content due to CLA, specifically trans-10, cis-12 CLA, is commonly associated with increased hepatic lipogenesis [30]. In mice, CLA has been repeatedly shown to increase the expression of sterol regulatory elementbinding protein-1c (SREBP-1c), key transcriptional regulator in hepatic lipogenesis and its downstream genes acetyl CoA carboxylase (ACC), fatty acid synthase (FASN), and stearoyl CoA desaturase-1 (SCD1) [30, 34, 35] (Table 2). However, in rats and hamsters, the responses are equivocal. The increase in SREBP-1c expression in mice is attributed to hyperinsulinemia (Figure 1) [30]. The decreased expression of lipogenic (ACC1, ACC2, FASN, and SCD1) genes in the absence of insulin in mice fed trans-10, cis-12 CLA further supports this argument [33]. In addition to SREBP$1 c$, insulin induces the expression of peroxisome proliferatoractivated receptor- $\gamma$ (PPAR- $\gamma$ ) [90], which is in low abundance under normal conditions [91]. PPAR- $\gamma$ expression is increased in steatotic liver (Figure 1) [30, 92], while its 
TABLE 1: Studies showing that trans-10, cis-12 CLA induced significant $(P<0.05)$ increases or decreases, or where there was no change $(P>$ $0.05)$ in body, adipose, and liver weights and liver lipid concentration.

\begin{tabular}{|c|c|c|c|c|c|}
\hline Species & Change & Body weight & Adipose tissue & Liver weight & Liver lipids \\
\hline \multirow{3}{*}{ Mice $^{1}$} & Increase & - & - & $24(92)$ & $19(515)$ \\
\hline & Decrease & $21(31)^{2}$ & $29(666)$ & - & - \\
\hline & No change & 16 & - & 2 & 2 \\
\hline \multirow{3}{*}{ Rats $^{3}$} & Increase & - & - & - & $1(25)$ \\
\hline & Decrease & - & $1(23)$ & - & $4(19)$ \\
\hline & No change & 11 & 3 & 8 & 4 \\
\hline \multirow{3}{*}{ Hamsters $^{4}$} & Increase & - & - & $8(20)$ & - \\
\hline & Decrease & $2(14)$ & $11(20)$ & - & $3(37)$ \\
\hline & No change & 11 & 2 & 2 & 5 \\
\hline \multirow{3}{*}{ Humans $^{5}$} & Increase & - & - & - & - \\
\hline & Decrease & 2 & 6 & - & - \\
\hline & No change & 11 & 13 & - & - \\
\hline
\end{tabular}

${ }^{1}$ Studies used: [22, 25, 27-48].

${ }^{2}$ Number of observations (mean percent change).

${ }^{3}$ Studies used: [49-53].

${ }^{4}$ Studies used: [54-62].

${ }^{5}$ Studies used: [63-81].

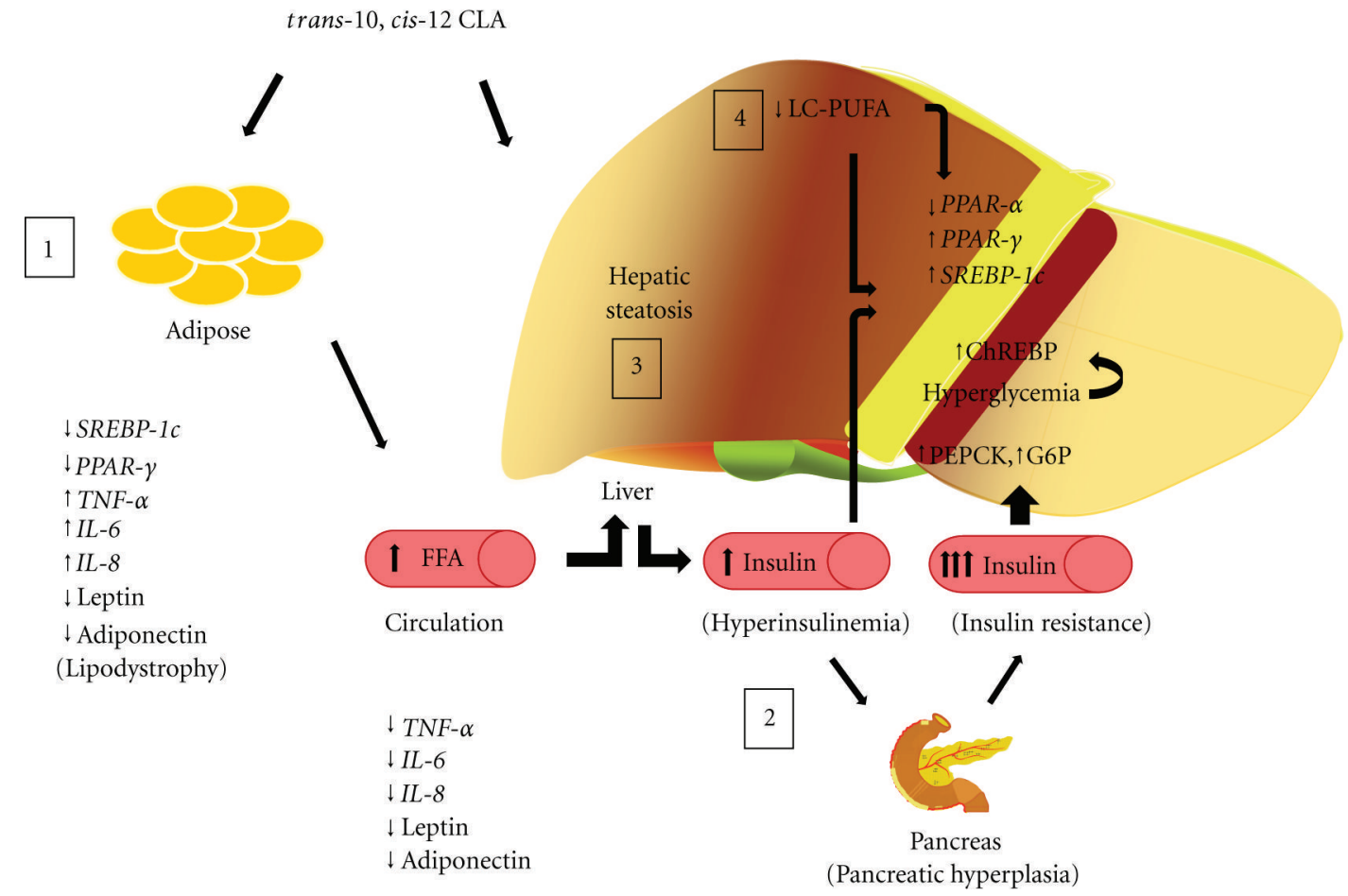

FIGURE 1: Current concepts in the pathways of trans-10, cis-12 CLA-induced hepatic steatosis. (1) Adipose tissue lipodystrophy caused by increased proinflammatory cytokines and reduced adipokines leading to higher circulatory levels of free FA (FFA). (2) Hyperinsulinemia induced by systemic insulin resistance. (3) Alterations in hepatic lipid metabolism leading to hepatic steatosis. (4) Alterations in hepatic FA composition. SREBP-1c, Sterol regulatory element-binding protein-1c; PPAR- $\gamma$, peroxisome proliferator activated receptor- $\gamma$; TNF- $\alpha$, tumor necrosis factor- $\alpha$; IL-6, interleukin-6; IL-8, interleukin-8; PEPCK, phosphoenol pyruvate carboxykinase; G6P, glucose 6-phosphatase; ChREBP, carbohydrate response element-binding protein; PPAR- $\alpha$, peroxisome proliferator-activated receptor- $\alpha$; LC-PUFA, long chain polyunsaturated FA. 
ablation ameliorates the condition in mice [93]. Insulin resistance in response to trans-10, cis-12 CLA could upregulate genes of glucogenic pathway (e.g., PEPCK, G6P) leading to hyperglycemia (Figure 1) [94]. In turn, elevated blood glucose concentrations could upregulate hepatic lipogenesis through carbohydrate response element binding protein (ChREBP), a transcriptional regulator modulated by glucose (Figure 1). The targeted deletion of ChREBP in the liver improves the steatotic conditions in $o b / o b$ mice [94]. However, the role of ChREBP in CLA-induced hepatic steatosis is not known. Although hyperinsulinemia triggers the hepatic lipogenesis, CLA-induced hepatic steatosis in the absence of insulin suggests the involvement of other regulatory mechanisms affecting hepatic lipid accumulation [33].

3.2.2. Hepatic FA Uptake and TG Secretion. In mouse experiments, dietary trans-10, cis-12 CLA was associated with upregulation of genes associated with FA uptake and TG secretion (FAT/CD36; Table 2). During hepatic steatosis about $59 \%$ of hepatic TG is derived from free FA released from the adipose tissue and $15 \%$ is derived from dietary fat [89]. FA transporters, (FATP5, FAT/CD36, FABP-1, FABP-4, and $F A B P-5)$ regulate the FA uptake by hepatocytes. While the overexpression of these proteins promotes steatosis, functional deletion ameliorates the condition [98-100]. As CLA are natural ligands and activators of PPAR- $\gamma$ [101] the upregulation of FAT/CD36 by trans-10, cis-12 CLA [32, 33, 102] could be through $P P A R-\gamma$ leading to increased hepatic FA uptake. In addition to FAT/CD36, we have observed modest increases in the expression of FABP-1 (1.39 fold) and FABP-2 (1.7 fold) in liver of lactating mice fed trans-10, cis12 CLA (Kadegowda, A. K. G., Erdman, R. A., and Loor, J. J., unpublished results).

Besides enhanced FA uptake and lipogenesis, alteration in very low-density lipoprotein (VLDL) secretion rates could also result in liver fat accumulation [103]. The VLDL production and secretion is increased in response to elevated lipid concentrations. However, impaired or insufficient fat export via VLDL predisposes animal to hepatic steatosis [10]. Trans-10, cis-12 CLA reduced TG secretion leading to higher lipid accumulation in HepG2 cells due to reduced apolipoprotein B synthesis [104]. Conversely, lipoprotein clearance was not affected in mice fed CLA [31, 102]. The TG export was increased with higher rate of VLDL secretion; however, it was insufficient to eliminate increased FA flux entering the liver leading to hepatic steatosis [31].

3.2.3. Hepatic FA Oxidation. Hepatic FA oxidation encompasses $\beta$-oxidation in mitochondria and peroxisomes and $\omega$ oxidation in the microsomes [105]. The FA < C8 to C20 are catabolized through the mitochondrial $\beta$-oxidation pathway, while FA > C20 are initially catabolized in the peroxisomes to shorter FA which are then shuttled to mitochondria for further oxidation [32]. Previous studies have reported variable responses in hepatic FA oxidation with trans-10, cis-12 CLA. Most of the studies have shown increased FA oxidation $[27,34,36,56,106]$, while some have reported reduced [32] or unaltered FA oxidation [22] with CLA.
Carnitine palmitoyltransferase-1 (CPT1) is the rate limiting enzyme for mitochondrial $\beta$-oxidation pathway, as it regulates the transport of fatty acyl CoA into mitochondria. When measured in mice, CPT1 gene expression was consistently increased by CLA (Table 2) which might be mediated through transcriptional regulator PPAR- $\alpha$ as it regulates the key enzymes (e.g., CPT1, CPT2, and ACO) involved in hepatic FA oxidation [50].

Despite increased FA oxidation hepatic steatosis was consistently observed in mice (Tables 1 and 2). Since studies showing increased FA oxidation were also associated with increased hepatic lipogenesis, it is possible that that the rates of hepatic lipogenesis far exceed the rates of FA oxidation resulting in increased lipid accumulation. Along with increased lipogenesis the level of malonyl CoA, a product of $A C C$, was also increased that allosterically inhibits CPT1 enzyme activity [36]. Thus, despite higher expression of FA oxidation genes, it is possible that FA combustion might be depressed in vivo leading to steatosis.

Some studies have shown CLA induced downregulation of genes related to mitochondrial $\beta$-oxidation (CPT1), and $\omega$ oxidation (cyt P450 and FMO3) [32]. We have also observed decreased expression of CPT1, ACOX1, and FMO3 without any changes in hepatic lipogenic genes of lactating mice fed trans-10, cis-12 CLA (Kadegowda, A. K. G., Erdman, R. A., and Loor, J. J., unpublished results). The variable responses among different studies can be attributed to the level and type of fat used in the experimental diet along with the physiological conditions of animal used in the experiment.

3.2.4. Effect of CLA on Hepatic FA Composition. Trans10, cis-12 CLA-induced hepatic steatosis is characterized by changes in hepatic FA composition [29, 37, 107-111] similar to those induced during NAFLD [112]. The hepatic FA composition in steatotic liver determines the extent of susceptibility of liver injury [113]. The steatotic liver FA profile is characterized by substantial reductions in long chain polyunsaturated FA (LC-PUFA) concentrations; specifically that of arachidonic acid (C20:4n-6). While linoleic (18:2n$6)$ and $\alpha$-linolenic acid (18:3n-3) are unaltered, the concentrations of eicosapentaenoic acid (EPA, C20:5n-3) and docosahexaenoic acid (DHA, C22:6n-3) are decreased. The desaturation and elongation of linoleic and $\alpha$-linolenic acid by desaturases $\left(\Delta^{5}\right.$-desaturase, $\Delta^{6}$-desaturase $)$ and elongases (ELOVL-2, ELOVL-3) are involved in synthesis of LC-PUFA. Trans-10, cis-12 CLA inhibits both $\Delta^{5}$ - and $\Delta^{6}$-desaturase in HepG2 cells [114]. A recent tracer study with $\left[\mathrm{U}_{-}{ }^{13} \mathrm{C}\right]$ linoleic acid showed significant reduction in n-6 PUFA synthesis by inhibition of elongation and desaturation in the liver homogenates of neonatal pigs [115]. A decrease in arachidonic acid synthesis would alter eicosanoid metabolism and potentially reduce the synthesis of prostaglandin E2 $\left(\mathrm{PGE}_{2}\right)$ [116] which is known to have protective effects on liver [117].

Typical NAFLD is also characterized by increased n$6: n-3$ LC-PUFA ratio which favors lipid synthesis over lipid oxidation and secretion leading to hepatic lipid accumulation [118]. Trans-10, cis-12 CLA reduces the n-3 PUFA in liver $[38,109]$ in addition to arachidonic acid. The 
TABle 2: Studies showing that trans-10, cis-12 CLA induced significant $(P<0.05)$ increases $(\uparrow)$, decreases $(\downarrow)$, or no change $(\leftrightarrow)(P>0.05)$ in hepatic gene expression and circulating levels of insulin, adipokines, and TNF- $\alpha$. Genes are classified based on their ascribed function.

\begin{tabular}{|c|c|c|c|c|c|c|c|c|c|}
\hline & \multicolumn{3}{|c|}{ Mice $^{1}$} & \multicolumn{3}{|c|}{ Rats $^{2}$} & \multicolumn{3}{|c|}{ Hamsters $^{3}$} \\
\hline & $\uparrow$ & $\downarrow$ & $\leftrightarrow$ & $\uparrow$ & $\downarrow$ & $\leftrightarrow$ & $\uparrow$ & $\downarrow$ & $\leftrightarrow$ \\
\hline \multicolumn{10}{|c|}{ Lipogenesis } \\
\hline$A C C$ & $5(126)^{4}$ & - & 1 & - & - & - & $1(99)$ & - & 1 \\
\hline FASN & $7(243)$ & - & 1 & - & $1(50)$ & 2 & - & - & 2 \\
\hline SCD1 & $2(150)$ & - & 3 & - & $1(80)$ & - & - & - & - \\
\hline$S R E B P-1 c$ & $3(53)$ & - & 2 & - & $1(40)$ & 4 & - & - & 3 \\
\hline PPAR- $\gamma$ & $2(200)$ & - & - & - & - & 2 & - & - & - \\
\hline$M E$ & $5(205)$ & - & - & - & - & - & - & - & - \\
\hline \multicolumn{10}{|c|}{ FA uptake, secretion, and oxidation } \\
\hline CPT1 & $4(107)$ & $1(59)$ & 1 & - & - & - & - & - & 2 \\
\hline$A C O$ & $5(117)$ & - & 1 & $2(130)$ & - & 4 & - & - & 2 \\
\hline PPAR- $\alpha$ & - & $1(53)$ & - & $1(125)$ & - & - & - & - & 3 \\
\hline FAT/CD36 & $3(533)$ & - & - & - & - & - & - & - & - \\
\hline$L P L$ & - & - & 1 & - & - & - & - & - & 1 \\
\hline \multicolumn{10}{|c|}{ Insulin, adipokines, and TNF $\alpha$} \\
\hline Insulin & $12(2492)$ & $1(29)$ & 3 & - & - & 3 & - & - & 1 \\
\hline Adiponectin & - & $6(77)$ & 5 & - & - & - & - & - & - \\
\hline Leptin & - & $10(71)$ & - & - & - & 1 & - & - & - \\
\hline TNF- $\alpha$ & - & $4(32)$ & 1 & & $1(44)$ & 2 & - & - & - \\
\hline
\end{tabular}

$\uparrow, \downarrow, \leftrightarrow ;$ increase, decrease or no changes respectively.

${ }^{1}$ Studies used: $[27,29-35,45,95,96]$.

${ }^{2}$ Studies used: [49-52, 97].

${ }^{3}$ Studies used: $[54,56,59,61]$.

${ }^{4}$ Number of observations (mean percent change).

ACC: acetyl CoA carboxylase, FASN: fatty acid synthase, SCD1: stearoyl CoA desaturase-1, SREBP-1c: sterol regulatory element-binding protein-1c, PPAR$\gamma$ : peroxisome proliferator activated receptor- $\gamma$, ME: malic enzyme, CPT1: carnitine palmitoyl transferase 1, ACO: acyl-CoA oxidase, PPAR $\alpha$ : peroxisomal proliferator activated receptor $\alpha$; FAT/CD36: fatty acid translocase, LPL: lipoprotein lipase.

n-3 PUFA downregulate SREBP-1c and upregulate PPAR$\alpha$, which regulates lipid oxidation $(C P T 1, A C O X 1)$ and secretion (ApoB100). A decrease in hepatic n-3 PUFA would not only reduce lipid oxidation but increase lipogenesis leading to hepatic steatosis [118]. Although the trans-10, cis-12 CLA-induced responses in FA oxidation are variable in mice, consistently increased lipogenesis (Table 2) suggests a potential role for $n-3$ PUFA. On the contrary, CLA feeding increased n-3 PUFA content and decreased n-6 PUFA in the rats $[119,120]$ which could probably explain the differences in CLA effects between the two species. Although the exact mechanism of CLA action has not been elucidated, Banni et al. [121] has suggested that the metabolites of CLA, conjugated dienes (CD) 18:3, CD20:3, CD20:4, could compete with other PUFA at the level of formation and metabolism in liver and affect LC-PUFA synthesis.

3.3. CLA and SCD in Hepatic Lipid Metabolism. In the adipose, there are some similarities between the effects of trans10 , cis-12 CLA and the inhibition of SCD1. For example, reduced adiposity is observed with both dietary trans-10, cis-12 CLA and SCD1 inhibition and one could speculate that the effects of trans-10, cis-12 CLA are mediated through SCD1 as trans-10, cis-12 CLA decreases SCD1 in adipose [122]. However, a study with $S C D 1^{-/-}$mice showed that the antiobesity effects of trans-10, cis-12 CLA were independent of $S C D 1$ gene expression and enzyme activity [123].

Unlike adipose, the effects of trans-10, cis-12 CLA are varied in liver (Table 2). While trans-10, cis-12 CLA decreased hepatic SCD activity in vitro [124], in vivo studies report increased hepatic SCD1 gene expression [32, 95]. In contrast to trans-10, cis-12 CLA effects in mice, SCD1 $1^{-/-}$ mice showed increased insulin sensitivity, reduced hepatic lipogenic genes, upregulated lipid oxidizing genes, increased hepatic saturated FA and unchanged hepatic n-3 and n-6 PUFA [125]. SCD1 $1^{-/-}$mice fed trans-10, cis-12 CLA showed reduced hepatic accumulation compared to wild type [123] confirming that reduced SCD1 expression decreases hepatic lipid accumulation [126]. Liver specific SCD1 knock out decreased expression of SREBP1 and ChREBP and their target genes there by reducing hepatic lipogenesis [127]. In contrast, short-term inhibition of tissue specific hepatic $S C D$ increased hepatic TG content and enhanced insulin signaling, [128] but the long-term inhibition decreased hepatic steatosis [129]. The differences in responses observed in liver specific knockout versus complete $S C D$ knockout mice suggests that hepatic lipid metabolism is being affected by lipid metabolism in nonhepatic tissues [130].

As trans-10, cis-12 CLA effects in mice are mostly associated with insulin resistance; increased hepatic SCD1 
expression is probably due to increased SREBP-1c expression. Hepatic steatosis due to trans-10, cis-12 CLA is also seen in the absence of insulin and is associated with reduced expression of $S C D 1$ and other lipogenic genes [33]. These results indicate that the disturbances in hepatic lipid metabolism caused by dietary trans-10, cis-12 CLA are mediated by multiple mechanisms [131] rather than through changes in $S C D 1$ alone.

3.4. Role of Adipose during CLA-Induced Hepatic Steatosis. The effect of CLA on adipose lipid metabolism is well documented [14]. Of all the CLA isomers, trans-10, cis-12 CLA is the most potent to induce changes in adipose [25]. The changes may be caused by reduced lipid content, size, and number of adipocytes. Trans-10, cis-12 CLA reduces lipogenesis by decreasing expression of SREBP-1c and PPAR$\gamma$ and their downstream genes, ACC, FASN, and SCD1, reduces glucose and FA uptake by reducing GLUT4 and $L P L$ expression, increases FA oxidation by increasing CPT1 and UCP2 expression and reduces adipocyte proliferation and differentiation by reducing $P P A R-\gamma$ and its downstream genes [131]. Furthermore, CLA affects various adipocyte secreted-adipokines (e.g., leptin, adiponectin, and resistin) and cytokines (e.g., TNF $\alpha$ and IL6), which are involved in wide range of physiological activities [14]. Trans-10, cis-12 CLA increases the mRNA expression of cytokines, TNF $\alpha$ and IL6 in adipose tissue [131]. However, the circulating cytokine levels are reduced in response to trans-10, cis-12 CLA (Table 2). The increased cytokine expression in adipose tissue is known to reduce the activity of PPAR- $\gamma$ [132], and thereby affect its downstream cellular functions. Also, TNF $\alpha$ and IL6 inhibit the activation of insulin receptor substrate-1 (IRS1) through induction of suppressors of cytokine signaling (SOCS3) disrupting insulin action [133]. The expressions of $T N F \alpha$ and adiponectin, an adipokine associated with insulin sensitivity, are inversely related [134]. The adipose tissue depletion would reduce the level of adiponectin and when coupled with increased TNF $\alpha$ would lead to severe insulin resistance. The subsequent pancreatic $\beta$ cell hyperplasia, as a compensatory mechanism to insulin resistance, leads to hyperinsulinemia which promotes lipid accretion in the liver leading to hepatic steatosis [39].

In mice, trans-10, cis-12 CLA causes severe lipodystrophy reducing the levels of leptin and adiponectin (Table 2), which leads to hepatic steatosis (Table 1, Figure 1). Re-establishing the levels of leptin or adiponectin either through external supplementation (in case of leptin) or induction using rosiglitazone (ROSI) (in case of adiponectin) attenuated hepatic steatotic condition and normalized the insulin levels in CLA-fed mice $[135,136]$. Similar results are seen in studies where prevention of lipodystrophy prevented lipid accumulation in the liver [135]. Serum insulin levels are directly correlated with liver TG, while serum adiponectin levels are inversely related [35]. Adipokines could improve the condition of the liver by lowering the insulin levels. However, hepatic steatosis is seen in mice even at low insulin levels [33], suggesting that different mechanisms could regulate the induction of hepatic steatosis depending on the animal's physiological condition. The intensity of hepatic steatosis could be directly related to the relative amounts of adipose tissue. CLA-induced hyperinsulinemia and hepatic steatosis are observed only if there are corresponding decreases in the adipose tissue mass [40, 135]. Stout et al. [137], reported increases in diacylglycerol (DAG) concentration and membrane associated protein kinase $C$ (PKC) during trans-10, cis-12 CLA-induced hepatic steatosis. Increased $P K C$ would affect insulin signaling leading to insulin resistance, hyperinsulinemia, and hyperglycemia [137].

3.5. CLA and Inflammatory Responses. In addition to its effects on lipid metabolism, trans-10, cis-12 CLA also induces an inflammatory response in adipose tissue [131, 138]. Trans-10, cis-12 CLA activates integrated stress response leading to activation of NF-kB pathway, induction of inflammatory cytokines, TNF $\alpha$, IL6, and IL $8[41,138,139]$, and macrophage infiltration [35]. However, the level of circulating cytokines, TNF $\alpha$ and IL6, were decreased in response to trans-10, cis-12 CLA $[42,43]$. In contrast to the adipose, the effects of CLA on hepatic inflammatory responses are not well defined. Trans-10, cis-12 CLA did not affect expression markers of macrophage infiltration in mice liver such as $T N F \alpha$ or $F 4 / 80$ and $C D 68$ during hepatic steatosis [35]. However, trans-10, cis-12 CLA increased expression of markers of hepatic inflammation in hamsters without inducing hepatic steatosis [57]. The authors in [57] attributed this to an increased capacity of the liver for higher FA oxidation leading to inflammation and oxidant stress defense pathway in the hamsters.

\section{Prevention or Amelioration of CLA-Induced Hepatic Steatosis}

Several studies have examined either the prevention or amelioration of trans-10, cis-12 CLA-induced hepatic steatosis (Table 3) by normalizing serum adipokine levels, altering hepatic PUFA composition or both. External supplementation of recombinant murine leptin ameliorate CLA-induced hepatic steatosis and hyperinsulinemia by decreasing hepatic lipogenesis and increasing insulin sensitivity respectively $[40,136]$. Serum adiponectin levels were not restored (and remained low) even after leptin supplementation, prompting the authors in [136] to claim that leptin alone could ameliorate CLA induced steatosis. Conversely, trans-10, cis-12 CLAcaused hyperinsulinemia associated with lipid steatosis in $\mathrm{Ob} / \mathrm{Ob}$ mouse which lack functional leptin [143] suggests the involvement of other factors. Increasing adiponectin levels by supplementation of ROSI attenuates liver fat accumulation in $\mathrm{Ob} / \mathrm{Ob}$ mouse [49]. ROSI prevented lipodystrophy, decreased hepatic lipogenesis and subsequently liver TG content [35]. The insulin sensitizing action of leptin and adiponectin normalizes insulin levels which further helps in preventing CLA-induced steatosis $[40,141]$.

Dietary FA or oil supplements with higher n-3 and n-6 PUFA are able to ameliorate liver steatosis when supplemented along with CLA. Supplementing arachidonic acid [140] or its precursor $\gamma$-linolenic acid (18:3n-6) [44] decreased induction of hepatic steatosis and increased liver 
TABLE 3: Summary of literature studies on amelioration of CLA induced hepatic steatosis.

\begin{tabular}{|c|c|c|c|c|c|c|c|}
\hline \multirow[b]{2}{*}{ Reference } & \multicolumn{6}{|c|}{$\%$ Added dietary CLA } & \multirow[b]{2}{*}{ Observations } \\
\hline & $\begin{array}{l}\text { No. per } \\
\text { treatment }\end{array}$ & Study days & CLA Mix & $\begin{array}{l}\text { trans }-10 \\
\text { cis }-12\end{array}$ & Treatment & $\begin{array}{l}\text { Treatment dose, } \\
\%^{1}\end{array}$ & \\
\hline$[136]$ & 3 to 6 & 28 & 2.0 & 0.95 & Leptin & $5 \mu \mathrm{g} / \mathrm{d}$ & $\begin{array}{l}\downarrow \text { Hepatic steatosis, } \uparrow \text { insulin } \\
\text { sensitivity, }\end{array}$ \\
\hline$[40]$ & 5 to 14 & 30 & 1.0 & 0.72 & Leptin & $5 \mu \mathrm{g} / \mathrm{d}$ & $\begin{array}{l}\uparrow \text { insulin sensitivity, amelio- } \\
\text { rated hepatic steatosis }\end{array}$ \\
\hline [49] & 5 & 28 & 1.5 & 0.60 & Rosiglitazone & $10 \mathrm{mg} / \mathrm{kg} \mathrm{BW}$ & $\begin{array}{l}\uparrow \text { Insulin sensitivity, pre- } \\
\text { vented depletion of epi- } \\
\text { didymal adipose tissue }\end{array}$ \\
\hline [35] & 10 & 42 & 2.0 & 1.00 & Rosiglitazone & $10 \mathrm{mg} / \mathrm{kg}$ BW & $\begin{array}{l}\downarrow \text { Hepatic TG content, } \\
\text { hepatic lipogenesis, } \uparrow \text { serum } \\
\text { leptin and adiponectin, pre- } \\
\text { vents lipodystrophy }\end{array}$ \\
\hline$[140]$ & 7 & 28 & 3.0 & 0.98 & $\begin{array}{l}\text { Arachidonic } \\
\text { acid }\end{array}$ & 1,2 & $\begin{array}{l}\downarrow \text { Induction of hepatic } \\
\text { steatosis, } \uparrow \text { liver PGE2, } \uparrow \\
\text { epididymal adipose }\end{array}$ \\
\hline$[44]$ & 7 & 28 & - & 1.20 & $\begin{array}{l}\gamma \text {-Linolenic } \\
\text { acid }\end{array}$ & 5 & $\downarrow$ Hepatic steatosis, $\uparrow \mathrm{PGE}_{2}$ \\
\hline$[38]$ & 10 & 56 & - & 0.50 & $\begin{array}{l}\text { Flax seed oil } \\
(\alpha \text { - Linolenic } \\
\text { acid })\end{array}$ & 0.39 & $\begin{array}{l}\downarrow \text { Steatosis, } \uparrow \mathrm{n}-3 \text { and n-6 } \\
\text { PUFA in liver }\end{array}$ \\
\hline [27] & 7 to 8 & 22 & 1.0 & 0.50 & Fish oil & $1.5,3,6$ & $\begin{array}{l}\uparrow \text { Leptin and Adiponectin, } \downarrow \\
\text { Insulin, } \downarrow \text { TG in liver, } \uparrow \text { fat } \\
\text { pad }\end{array}$ \\
\hline$[141]$ & 10 & 105 & 1.0 & 0.50 & Pine oil & 7.5 & $\begin{array}{l}\text { Serum insulin levels stabi- } \\
\text { lized over } 3 \text { weeks }\end{array}$ \\
\hline$[135]$ & 5 to 6 & 100 & 1.0 & 0.35 & $\begin{array}{l}34 \% \text { dietary } \\
\text { fat }\end{array}$ & & $\begin{array}{l}\text { Normal plasma insulin lev- } \\
\text { els, } \uparrow \text { liver weight }\end{array}$ \\
\hline$[45]$ & 6 & 28 & 2.0 & 0.74 & DHA & 0.5 & $\begin{array}{l}\downarrow \text { Fatty liver, } \downarrow \text { FA syn- } \\
\text { thesis, plasma leptin, and } \\
\text { adiponectin unaffected }\end{array}$ \\
\hline$[142]$ & 10 & 56 & - & 0.50 & DHA, EPA & $0.5,0.5$ & $\begin{array}{l}\text { Prevented hepatic steatosis, } \\
\text { partially restored plasma } \\
\text { leptin, only DHA restored } \\
\text { plasma adiponectin }\end{array}$ \\
\hline
\end{tabular}

${ }^{1}$ Percentage in the diet except wherever noted.

$\mathrm{PGE}_{2}$ levels. Hepatic steatosis is characterized by significant reduction in the levels of arachidonic acid in liver. Arachidonic acid supplementation would not only normalize the level of respective FA but would also increase the levels of hepatic $\mathrm{PGE}_{2}[44,140]$. Both arachidonic acid and $\mathrm{PGE}_{2}$ would further reduce hepatic lipogenesis by decreasing FASN and S14 gene expression [140, 144] thereby preventing hepatic steatosis.

The importance of n-3 PUFA concentrations on hepatic lipid metabolism was explained in the earlier section. Trans10, cis-12 CLA decreases liver n-3 PUFA concentrations which affect hepatic lipid metabolism. Dietary supplements enriched in n-3 PUFA along with CLA diet increased the content of n-3 and n-6 PUFA in liver [38]. Fish oil, a source of PUFA has been shown to ameliorate CLA-induced steatosis by increasing leptin and adiponectin levels and decreasing plasma insulin [27]. Pinolenic oil, a source of Pinolenic acid was able to stabilize insulin levels when fed with CLA
[141]. Similarly, flaxseed oil, a source of $\alpha$-linolenic acid was able to increase n-3 and n-6 PUFA in liver. Supplementing EPA and DHA prevents lipid accumulation when fed with trans-10, cis-12 CLA [45, 142]. This effect was independent of their effects on stabilizing insulin sensitivity. Both EPA and DHA have modest effects in restoring plasma leptin levels, while DHA alone can restore plasma adiponectin levels to some extent [142]. The effects of DHA in preventing hepatic steatosis were mediated through decreasing hepatic lipogenesis [45].

\section{Role of cis-9, trans-11 CLA in Hepatic Metabolism}

Of the 16 naturally occurring CLA isomers, trans-10, cis- 12 CLA and cis-9, trans-11 CLA have been the most extensively studied with respect to their bioactive properties. Most 
of the animal studies have used a CLA mixture having trans-10, cis-12 CLA and cis-9, trans-11 CLA in $1: 1$ ratio to study the effect of CLA on liver metabolism. Studies using purified CLA isomer have delineated the differences between the two isomers. While trans-10, cis-12 CLA leads to decreased adipose tissue leading to insulin resistance, hyperinsulinemia, and hepatic steatosis, cis-9, trans-11 CLA shows only modest effects in mice $[30-32,86]$ and hamsters $[56,58]$. Similarly, the effects of CLA on SCD1 gene and protein expression are isomer specific [145]. Contrary to trans-10, cis-12 CLA, cis-9, trans-11 CLA has no effect on SCD1 gene expression either in vitro [124] or in vivo [95].

A few studies have reported beneficial effects of cis-9, trans-11 CLA. For example, cis-9, trans-11 CLA did not alter liver lipid content but reduced 18:1n-9 and 18:1n-7 and increased 18:2n-6 in TG in contrast to trans-10, cis-12 CLA [108]. In addition, cis-9, trans-11 CLA promotes insulin sensitivity $[42,43]$ by reducing adipose inflammation $[41,132]$. Furthermore, it enhances hepatic mitochondrial function and protects against oxidative stress by increasing activities of mitochondrial antioxidant enzymes [146]. The anti-inflammatory role of cis-9, trans-11 CLA is related to the induction of anti-inflammatory heat shock protein (HSP) $70 \mathrm{kDa}$ and decreased expression of proinflammatory macrophage migration inhibitory factor [147].

\section{Conclusions}

Hepatic steatosis induced by trans-10, cis-12 CLA is associated with lipodystrophy in addition to insulin resistance, hyperinsulinemia, and hyperglycemia in mice (Figure 1). These effects are largely attributed to decreased adipokine (leptin and adiponectin) secretion. Dietary interventions preventing lipodystrophy or normalizing leptin and adiponectin levels prevents or ameliorates hepatic steatosis in mice, suggesting that adipose tissue responsiveness to trans10, cis-12 CLA could be the main contributing factor. The moderate responsiveness of adipose tissue to trans-10, cis12 CLA observed in hamsters and rats results in lower (or absence of) hepatic TG accumulation when compared with mice (Table 1) explains species specific responses.

Hepatic steatosis, due to increased lipid accumulation, is multifactorial and is largely attributed to increased rates of lipid synthesis along with lipid uptake, and it far exceeds the rates of FA oxidation and VLDL secretion. In addition, trans10, cis-12 CLA-induced hepatic steatosis is characterized by reduction of n-6 PUFA (especially C20:4n-6) and n-3 PUFA (Figure 1). Changes in hepatic FA composition could play an important role in progression of hepatic steatosis, as normalizing the levels of n-6 PUFA or n-3 PUFA by dietary supplementation prevents or ameliorates hepatic lipid accumulation. Further studies are needed to understand the molecular mechanisms and the interrelationship between trans-10, cis12 CLA-induced hepatic steatosis and altered hepatic PUFA content. We are still lacking mechanistic details showing relationship between adipokine levels, insulin resistance, and hepatic FA composition in context of hepatic steatosis, and it needs to be addressed in the future experiments.

\section{Acknowledgment}

D. Vyas and A. K. G. Kadegowda contributed equally to this work.

\section{References}

[1] J. Salas-Salvadó, F. Márquez-Sandoval, and M. Bulló, “Conjugated Linoleic acid intake in humans: a systematic review focusing on its effect on body composition, glucose, and lipid metabolism," Critical Reviews in Food Science and Nutrition, vol. 46, no. 6, pp. 479-488, 2006.

[2] K. M. Flegal, M. D. Carroll, C. L. Ogden, and L. R. Curtin, "Prevalence and trends in obesity among US adults, 19992008," Journal of the American Medical Association, vol. 303, no. 3, pp. 235-241, 2010.

[3] C. L. Ogden, M. D. Carroll, L. R. Curtin, M. M. Lamb, and K. M. Flegal, "Prevalence of high body mass index in US children and adolescents, 2007-2008," Journal of the American Medical Association, vol. 303, no. 3, pp. 242-249, 2010.

[4] A. M. Zivkovic, J. B. German, and A. J. Sanyal, "Comparative review of diets for the metabolic syndrome: implications for nonalcoholic fatty liver disease," American Journal of Clinical Nutrition, vol. 86, no. 2, pp. 285-300, 2007.

[5] E. Fabbrini, S. Sullivan, and S. Klein, "Obesity and nonalcoholic fatty liver disease: biochemical, metabolic, and clinical implications," Hepatology, vol. 51, no. 2, pp. 679-689, 2010.

[6] A. J. McCullough, "The clinical features, diagnosis and natural history of nonalcoholic fatty liver disease," Clinics in Liver Disease, vol. 8, no. 3, pp. 521-533, 2004.

[7] J. K. Reddy and M. S. Rao, "Lipid metabolism and liver inflammation. II. Fatty liver disease and fatty acid oxidation," American Journal of Physiology, vol. 290, no. 5, pp. G852G858, 2006.

[8] F. Diraison, P. H. Moulin, and M. Beylot, "Contribution of hepatic de novo lipogenesis and reesterification of plasma non esterified fatty acids to plasma triglyceride synthesis during non-alcoholic fatty liver disease," Diabetes and Metabolism, vol. 29, no. 5, pp. 478-485, 2003.

[9] M. J. Ronis, Y. Chen, C. H. Jo, P. Simpson, and T. M. Badger, "Diets containing soy protein isolate increase hepatic CYP3A expression and inducibility in weanling male rats exposed during early development," Journal of Nutrition, vol. 134, no. 12, pp. 3270-3276, 2004.

[10] M. Charlton, R. Sreekumar, D. Rasmussen, K. Lindor, and K. S. Nair, "Apolipoprotein synthesis in nonalcoholic steatohepatitis," Hepatology, vol. 35, no. 4, pp. 898-904, 2002.

[11] H. L. Huang, W. Y. Lin, L. T. Lee, H. H. Wang, W. J. Lee, and K. C. Huang, "Metabolic syndrome is related to nonalcoholic steatohepatitis in severely obese subjects," Obesity Surgery, vol. 17, no. 11, pp. 1457-1463, 2007.

[12] Z. Z. Li, M. Berk, T. M. McIntyre, and A. E. Feldstein, "Hepatic lipid partitioning and liver damage in nonalcoholic fatty liver disease: role of stearoyl-Coa desaturase," Journal of Biological Chemistry, vol. 284, no. 9, pp. 5637-5644, 2009.

[13] C. P. Day and O. F. W. James, "Steatohepatitis: a tale of two 'Hits," Gastroenterology, vol. 114, no. 4 I, pp. 842-845, 1998.

[14] Y. Park and M. W. Pariza, "Mechanisms of body fat modulation by conjugated linoleic acid (CLA)," Food Research International, vol. 40, no. 3, pp. 311-323, 2007.

[15] M. W. Pariza, Y. Park, and M. E. Cook, "The biologically active isomers of conjugated linoleic acid," Progress in Lipid Research, vol. 40, no. 4, pp. 283-298, 2001. 
[16] K. Eulitz, M. P. Yurawecz, N. Sehat et al., "Preparation, separation, and confirmation of the eight geometrical cis/trans conjugated linoleic acid isomers 8, 10- through 11, 13-18:2," Lipids, vol. 34, no. 8, pp. 873-877, 1999.

[17] N. Sehat, R. Rickert, M. M. Mossoba et al., "Improved separation of conjugated fatty acid methyl esters by silver ion-high-performance liquid chromatography," Lipids, vol. 34, no. 4, pp. 407-413, 1999.

[18] P. W. Parodi, "Conjugated octadecadienoic acids of milk-fat," Journal of Dairy Science, vol. 60, no. 10, pp. 1550-1553, 1977.

[19] S. F. Chin, W. Liu, J. M. Storkson, Y. L. Ha, and M. W. Pariza, "Dietary sources of conjugated dienoic isomers of linoleic acid, a newly recognized class of anticarcinogens," Journal of Food Composition and Analysis, vol. 5, no. 3, pp. 185-197, 1992.

[20] K. N. Lee, D. Kritchevsky, and M. W. Parizaa, "Conjugated linoleic acid and atherosclerosis in rabbits," Atherosclerosis, vol. 108, no. 1, pp. 19-25, 1994.

[21] C. C. Miller, Y. Park, M. W. Pariza, and M. E. Cook, "Feeding conjugated linoleic acid to animals partially overcomes catabolic responses due to endotoxin injection," Biochemical and Biophysical Research Communications, vol. 198, no. 3, pp. 1107-1112, 1994.

[22] Y. Park, K. J. Albright, W. Liu, J. M. Storkson, M. E. Cook, and M. W. Pariza, "Effect of conjugated linoleic acid on body composition in mice," Lipids, vol. 32, no. 8, pp. 853-858, 1997.

[23] C. Ip, Y. Dong, M. M. Ip et al., "Conjugated linoleic acid isomers and mammary cancer prevention," Nutrition and Cancer, vol. 43, no. 1, pp. 52-58, 2002.

[24] M. A. Belury, "Inhibition of carcinogenesis by conjugated linoleic acid: potential mechanisms of action," Journal of Nutrition, vol. 132, no. 10, pp. 2995-2998, 2002.

[25] Y. Park, J. M. Storkson, K. J. Albright, W. Liu, and M. W. Pariza, "Evidence that the trans-10,cis-12 isomer of conjugated linoleic acid induces body composition changes in mice," Lipids, vol. 34, no. 3, pp. 235-241, 1999.

[26] T. M. Larsen, S. Toubro, and A. Astrup, "Efficacy and safety of dietary supplements containing CLA for the treatment of obesity: evidence from animal and human studies," Journal of Lipid Research, vol. 44, no. 12, pp. 2234-2241, 2003.

[27] T. Ide, "Interaction of fish oil and conjugated linoleic acid in affecting hepatic activity of lipogenic enzymes and gene expression in liver and adipose tissue," Diabetes, vol. 54, no. 2, pp. 412-423, 2005.

[28] M. F. Andreoli, M. A. Gonzalez, M. I. Martinelli, N. O. Mocchiutti, and C. A. Bernal, "Effects of dietary conjugated linoleic acid at high-fat levels on triacylglycerol regulation in mice," Nutrition, vol. 25, no. 4, pp. 445-452, 2009.

[29] A. K. G. Kadegowda, E. E. Connor, B. B. Teter et al., "Dietary trans fatty acid isomers differ in their effects on mammary lipid metabolism as well as lipogenic gene expression in lactating mice," Journal of Nutrition, vol. 140, no. 5, pp. 919924, 2010.

[30] L. Clément, H. Poirier, I. Niot et al., "Dietary trans-10,cis-12 conjugated linoleic acid induces hyperinsulinemia and fatty liver in the mouse," Journal of Lipid Research, vol. 43, no. 9, pp. 1400-1409, 2002.

[31] P. Degrace, L. Demizieux, J. Gresti, J. M. Chardigny, J. L. Sébédio, and P. Clouet, "Association of liver steatosis with lipid oversecretion and hypotriglyceridaemia in C57BL/6j mice fed trans-10,cis-12-linoleic acid," FEBS Letters, vol. 546, no. 2-3, pp. 335-339, 2003.
[32] R. Rasooly, D. S. Kelley, J. Greg, and B. E. Mackey, "Dietary trans 10, cis 12-conjugated linoleic acid reduces the expression of fatty acid oxidation and drug detoxification enzymes in mouse liver," British Journal of Nutrition, vol. 97, no. 1, pp. 58-66, 2007.

[33] T. Jourdan, L. Djaouti, L. Demizieux, J. Gresti, B. Vergès, and P. Degrace, "Liver carbohydrate and lipid metabolism of insulin-deficient mice is altered by trans-10, cis-12 conjugated linoleic acid," Journal of Nutrition, vol. 139, no. 10, pp. 1901-1907, 2009.

[34] Y. Takahashi, M. Kushiro, K. Shinohara, and T. Ide, "Activity and mRNA levels of enzymes involved in hepatic fatty acid synthesis and oxidation in mice fed conjugated linoleic acid," Biochimica et Biophysica Acta, vol. 1631, no. 3, pp. 265-273, 2003.

[35] L. F. Liu, A. Purushotham, A. A. Wendel, and M. A. Belury, "Combined effects of rosiglitazone and conjugated linoleic acid on adiposity, insulin sensitivity, and hepatic steatosis in high-fat-fed mice," American Journal of Physiology, vol. 292, no. 6, pp. G1671-G1682, 2007.

[36] P. Degrace, L. Demizieux, J. Gresti, J. M. Chardigny, J. L. Sébédio, and P. Clouet, "Hepatic steatosis is not due to impaired fatty acid oxidation capacities in C57BL/6J mice fed the conjugated trans-10,cis-12-Isomer of Linoleic Acid," Journal of Nutrition, vol. 134, no. 4, pp. 861-867, 2004.

[37] M. A. Belury and A. Kempa-Steczko, "Conjugated linoleic acid modulates hepatic lipid composition in mice," Lipids, vol. 32, no. 2, pp. 199-204, 1997.

[38] D. S. Kelley, M. Vemuri, Y. Adkins, S. H. S. Gill, D. Fedor, and B. E. Mackey, "Flaxseed oil prevents trans-10, cis-12conjugated linoleic acid-induced insulin resistance in mice," British Journal of Nutrition, vol. 101, no. 5, pp. 701-708, 2009.

[39] H. Poirier, C. Rouault, L. Clément et al., "Hyperinsulinaemia triggered by dietary conjugated linoleic acid is associated with a decrease in leptin and adiponectin plasma levels and pancreatic beta cell hyperplasia in the mouse," Diabetologia, vol. 48, no. 6, pp. 1059-1065, 2005.

[40] N. Tsuboyama-Kasaoka, M. Takahashi, K. Tanemura et al., "Conjugated linoleic acid supplementation reduces adipose tissue by apoptosis and develops lipodystrophy in mice," Diabetes, vol. 49, no. 9, pp. 1534-1542, 2000.

[41] H. Poirier, J. S. Shapiro, R. J. Kim, and M. A. Lazar, "Nutritional supplementation with trans-10, cis-12-conjugated linoleic acid induces inflammation of white adipose tissue," Diabetes, vol. 55, no. 6, pp. 1634-1641, 2006.

[42] G. V. Halade, M. M. Rahman, and G. Fernandes, "Differential effects of conjugated linoleic acid isomers in insulin-resistant female C57Bl/6J mice," Journal of Nutritional Biochemistry, vol. 21, no. 4, pp. 332-337, 2010.

[43] G. V. Halade, M. M. Rahman, and G. Fernandes, "Effect of CLA isomers and their mixture on aging C57Bl/6J mice," European Journal of Nutrition, vol. 48, no. 7, pp. 409-418, 2009.

[44] T. Nakanishi, D. Oikawa, T. Koutoku et al., " $\gamma$-linolenic acid prevents conjugated linoleic acid-induced fatty liver in mice," Nutrition, vol. 20, no. 4, pp. 390-393, 2004.

[45] T. Yanagita, Y. M. Wang, K. Nagao, Y. Ujino, and N. Inoue, "Conjugated linoleic acid-induced fatty liver can be attenuated by combination with docosahexaenoic acid in C57BL/6N mice," Journal of Agricultural and Food Chemistry, vol. 53, no. 24, pp. 9629-9633, 2005.

[46] Y. Park, K. J. Albright, J. M. Storkson, W. Liu, M. E. Cook, and M. W. Pariza, "Changes in body composition in mice during 
feeding and withdrawal of conjugated linoleic acid," Lipids, vol. 34, no. 3, pp. 243-248, 1999.

[47] J. P. DeLany and D. B. West, "Changes in body composition with conjugated linoleic acid," Journal of the American College of Nutrition, vol. 19, no. 4, pp. 487S-493S, 2000.

[48] M. R. Foote, S. L. Giesy, G. Bernal-Santos, D. E. Bauman, and Y. R. Boisclair, "t10,c12-CLA decreases adiposity in peripubertal mice without dose-related detrimental effects on mammary development, inflammation status, and metabolism," American Journal of Physiology, vol. 299, no. 6, pp. R1521-R1528, 2010.

[49] A. Purushotham, G. E. Shrode, A. A. Wendel, L. F. Liu, and M. A. Belury, "Conjugated linoleic acid does not reduce body fat but decreases hepatic steatosis in adult Wistar rats," Journal of Nutritional Biochemistry, vol. 18, no. 10, pp. 676684, 2007.

[50] S. Y. Moya-Camarena, J. P. Vanden Heuvel, and M. A. Belury, "Conjugated linoleic acid activates peroxisome proliferatoractivated receptor $\alpha$ and $\beta$ subtypes but does not induce hepatic peroxisome proliferation in Sprague-Dawley rats," Biochimica et Biophysica Acta, vol. 1436, no. 3, pp. 331-342, 1999.

[51] J. S. Choi, M. H. Jung, H. S. Park, and J. Song, "Effect of conjugated linoleic acid isomers on insulin resistance and mRNA levels of genes regulating energy metabolism in highfat-fed rats," Nutrition, vol. 20, no. 11-12, pp. 1008-1017, 2004.

[52] T. Tsuzuki, M. Igarashi, and T. Miyazawa, "Conjugated Eicosapentaenoic acid (EPA) inhibits transplanted tumor growth via membrane lipid peroxidation in nude mice," Journal of Nutrition, vol. 134, no. 5, pp. 1162-1166, 2004.

[53] M. F. Andreoli, M. V. Scalerandi, I. M. Borel, and C. A. Bernal, "Effects of CLA at different dietary fat levels on the nutritional status of rats during protein repletion," Nutrition, vol. 23, no. 11-12, pp. 827-835, 2007.

[54] J. Miranda, I. Churruca, A. Fernández-Quintela et al., "Weak effect of trans-10, cis-12-conjugated linoleic acid on body fat accumulation in adult hamsters," British Journal of Nutrition, vol. 102, no. 11, pp. 1583-1589, 2009.

[55] A. Zabala, I. Churruca, A. Fernández-Quintela et al., “Trans10,cis-12 conjugated linoleic acid inhibits lipoprotein lipase but increases the activity of lipogenic enzymes in adipose tissue from hamsters fed an atherogenic diet," British Journal of Nutrition, vol. 95, no. 6, pp. 1112-1119, 2006.

[56] M. T. Macarulla, A. Fernández-Quintela, A. Zabala et al., "Effects of conjugated linoleic acid on liver composition and fatty acid oxidation are isomer-dependent in hamster," Nutrition, vol. 21, no. 4, pp. 512-519, 2005.

[57] V. Navarro, M. P. Portillo, A. Margotat et al., "A multigene analysis strategy identifies metabolic pathways targeted by trans-10, cis-12-conjugated linoleic acid in the liver of hamsters," British Journal of Nutrition, vol. 102, no. 4, pp. 537-545, 2009.

[58] V. Bissonauth, Y. Chouinard, J. Marin, N. Leblanc, D. Richard, and H. Jacques, "The effects of t10,c12 CLA isomer compared with c9,t11 CLA isomer on lipid metabolism and body composition in hamsters," Journal of Nutritional Biochemistry, vol. 17, no. 9, pp. 597-603, 2006.

[59] A. Lasa, E. Simón, I. Churruca et al., "Effects of trans-10,cis12 CLA on liver size and fatty acid oxidation under energy restriction conditions in hamsters," Nutrition, vol. 27, no. 1, pp. 116-121, 2011.

[60] E. Simón, M. T. MacArulla, I. Churruca, A. FernándezQuintela, and M. P. Portillo, "trans-10,cis-12 Conjugated linoleic acid prevents adiposity but not insulin resistance induced by an atherogenic diet in hamsters," Journal of Nutritional Biochemistry, vol. 17, no. 2, pp. 126-131, 2006.

[61] E. J. Tarling, K. J. P. Ryan, A. J. Bennett, and A. M. Salter, "Effect of dietary conjugated linoleic acid isomers on lipid metabolism in hamsters fed high-carbohydrate and high-fat diets," British Journal of Nutrition, vol. 101, no. 11, pp. 16301638, 2009.

[62] E. A. M. De Deckere, J. M. M. Van Amelsvoort, G. P. McNeill, and P. Jones, "Effects of conjugated linoleic acid (CLA) isomers on lipid levels and peroxisome proliferation in the hamster," British Journal of Nutrition, vol. 82, no. 4, pp. 309317, 1999.

[63] E. Thom, J. Wadstein, and O. Gudmundsen, "Conjugated linoleic acid reduces body fat in healthy exercising humans," Journal of International Medical Research, vol. 29, no. 5, pp. 392-396, 2001.

[64] K. L. Zambell, N. L. Keim, M. D. Van Loan et al., "Conjugated linoleic acid supplementation in humans: effects on body composition and energy expenditure," Lipids, vol. 35, no. 7, pp. 777-782, 2000.

[65] A. Petridou, V. Mougios, and A. Sagredos, "Supplementation with CLA: isomer incorporation into serum lipids and effect on body fat of women," Lipids, vol. 38, no. 8, pp. 805-811, 2003.

[66] C. Malpuech-Brugère, W. P. H. G. Verboeket-Van De Venne, R. P. Mensink et al., "Effects of two conjugated linoleic acid isomers on body fat mass in overweight humans," Obesity Research, vol. 12, no. 4, pp. 591-598, 2004.

[67] G. Berven, A. Bye, O. Hals et al., "Safety of conjugated linoleic acid (CLA) in overweight or obese human volunteers," European Journal of Lipid Science and Technology, vol. 102, no. 7, pp. 455-462, 2000.

[68] U. Risérus, B. Vessby, P. Arner, and B. Zethelius, "Supplementation with trans10cis12-conjugated linoleic acid induces hyperproinsulinaemia in obese men: close association with impaired insulin sensitivity," Diabetologia, vol. 47, no. 6, pp. 1016-1019, 2004.

[69] U. Riserus, P. Arner, K. Brismar et al., "Treatment with dietary trans10cis 12 conjugated linoleic add causes isomermspecific insulin resistance in obese men with the metabolic syndrome," Diabetes Care, vol. 25, no. 9, pp. 1516-1521, 2002.

[70] S. Basu, U. Risérus, A. Turpeinen, and B. Vessby, "Conjugated linoleic acid induces lipid peroxidation in men with abdominal obesity," Clinical Science, vol. 99, no. 6, pp. 511-516, 2000.

[71] P. Benito, G. J. Nelson, D. S. Kelley, G. Bartolini, P. C. Schmidt, and V. Simon, "The effect of conjugated linoleic acid on plasma lipoproteins and tissue fatty acid composition in humans," Lipids, vol. 36, no. 3, pp. 229-236, 2001.

[72] V. Mougios, A. Matsakas, A. Petridou et al., "Effect of supplementation with conjugated linoleic acid on human serum lipids and body fat," Journal of Nutritional Biochemistry, vol. 12, no. 10, pp. 585-594, 2001.

[73] R. B. Kreider, M. P. Ferreira, M. Greenwood, M. Wilson, and A. L. Almada, "Effects of conjugated linoleic acid supplementation during resistance training on body composition, bone density, strength, and selected hematological markers," Journal of Strength and Conditioning Research, vol. 16, no. 3, pp. 325-334, 2002.

[74] M. M. J. W. Kamphuis, M. P. G. M. Lejeune, W. H. M. Saris, and M. S. Westerterp-Plantenga, "Effect of conjugated linoleic acid supplementation after weight loss on appetite 
and food intake in overweight subjects," European Journal of Clinical Nutrition, vol. 57, no. 10, pp. 1268-1274, 2003.

[75] F. Moloney, T. P. Yeow, A. Mullen, J. J. Nolan, and H. M. Roche, "Conjugated linoleic acid supplementation, insulin sensitivity, and lipoprotein metabolism in patients with type 2 diabetes mellitus," American Journal of Clinical Nutrition, vol. 80, no. 4, pp. 887-895, 2004.

[76] L. D. Whigham, M. O’Shea, I. C. M. Mohede, H. P. Walaski, and R. L. Atkinson, "Safety profile of conjugated linoleic acid in a 12-month trial in obese humans," Food and Chemical Toxicology, vol. 42, no. 10, pp. 1701-1709, 2004.

[77] J. M. Gaullier, J. Halse, K. Høye et al., "Supplementation with conjugated linoleic acid for 24 months is well tolerated by and reduces body fat mass in healthy, overweight humans," Journal of Nutrition, vol. 135, no. 4, pp. 778-784, 2005.

[78] J. M. Gaullier, J. Halse, and K. Høye, "Conjugated linoleic acid supplementation for $1 \mathrm{y}$ reduces body fat mass in healthy overweight humans (vol 79, pg 1118, 2004)," American Journal of Clinical Nutrition, vol. 81, no. 2, p. 538, 2005.

[79] J. S. W. Taylor, S. R. P. Williams, R. Rhys, P. James, and M. P. Frenneaux, "Conjugated linoleic acid impairs endothelial function," Arteriosclerosis, Thrombosis, and Vascular Biology, vol. 26, no. 2, pp. 307-312, 2006.

[80] A. B. Thrush, A. Chabowski, G. J. Heigenhauser, B. W. McBride, M. Or-Rashid, and D. J. Dyck, "Conjugated linoleic acid increases skeletal muscle ceramide content and decreases insulin sensitivity in overweight, non-diabetic humans," Applied Physiology, Nutrition and Metabolism, vol. 32, no. 3, pp. 372-382, 2007.

[81] N. M. Racine, A. C. Watras, A. L. Carrel et al., "Effect of conjugated linoleic acid on body fat accretion in overweight or obese children," American Journal of Clinical Nutrition, vol. 91, no. 5, pp. 1157-1164, 2010.

[82] O. A. Gudbrandsen, E. Rodríguez, H. Wergedahl et al., "Trans-10, cis-12-conjugated linoleic acid reduces the hepatic triacylglycerol content and the leptin mRNA level in adipose tissue in obese Zucker fa/fa rats," British Journal of Nutrition, vol. 102, no. 6, pp. 803-815, 2009.

[83] L. D. Whigham, A. C. Watras, and D. A. Schoeller, "Efficacy of conjugated linoleic acid for reducing fat mass: a metaanalysis in humans," American Journal of Clinical Nutrition, vol. 85, no. 5, pp. 1203-1211, 2007.

[84] A. Bhattacharya, J. Banu, M. Rahman, J. Causey, and G. Fernandes, "Biological effects of conjugated linoleic acids in health and disease," Journal of Nutritional Biochemistry, vol. 17, no. 12, pp. 789-810, 2006.

[85] H. Blankson, J. A. Stakkestad, H. Fagertun, E. Thom, J. Wadstein, and O. Gudmundsen, "Conjugated linoleic acid reduces body fat mass in overweight and obese humans," Journal of Nutrition, vol. 130, no. 12, pp. 2943-2948, 2000.

[86] M. H. Cooper, J. R. Miller, P. L. Mitchell, D. L. Currie, and R. S. McLeod, "Conjugated linoleic acid isomers have no effect on atherosclerosis and adverse effects on lipoprotein and liver lipid metabolism in apoE-/- mice fed a high-cholesterol diet," Atherosclerosis, vol. 200, no. 2, pp. 294-302, 2008.

[87] C. L. Gentile and M. J. Pagliassotti, "The endoplasmic reticulum as a potential therapeutic target in nonalcoholic fatty liver disease," Current Opinion in Investigational Drugs, vol. 9, no. 10, pp. 1084-1088, 2008.

[88] F. Diraison and M. Beylot, "Role of human liver lipogenesis and reesterification in triglycerides secretion and in FFA reesterification," American Journal of Physiology, vol. 274, no. 2, pp. E321-E327, 1998.
[89] K. L. Donnelly, C. I. Smith, S. J. Schwarzenberg, J. Jessurun, M. D. Boldt, and E. J. Parks, "Sources of fatty acids stored in liver and secreted via lipoproteins in patients with nonalcoholic fatty liver disease," Journal of Clinical Investigation, vol. 115, no. 5, pp. 1343-1351, 2005.

[90] U. A. Boelsterli and M. Bedoucha, "Toxicological consequences of altered peroxisome proliferator-activated receptor $\gamma(\operatorname{PPAR} \gamma)$ expression in the liver: insights from models of obesity and type 2 diabetes," Biochemical Pharmacology, vol. 63, no. 1, pp. 1-10, 2002.

[91] P. Tontonoz, E. Hu, and B. M. Spiegelman, "Stimulation of adipogenesis in fibroblasts by PPAR $\gamma 2$, a lipid-activated transcription factor," Cell, vol. 79, no. 7, pp. 1147-1156, 1994.

[92] Y. L. Zhang, A. Hernandez-Ono, P. Siri et al., "Aberrant hepatic expression of PPAR $\gamma 2$ stimulates hepatic lipogenesis in a mouse model of obesity, insulin resistance, dyslipidemia, and hepatic steatosis," Journal of Biological Chemistry, vol. 281, no. 49, pp. 37603-37615, 2006.

[93] O. Gavrilova, M. Haluzik, K. Matsusue et al., "Liver peroxisome proliferator-activated receptor $\gamma$ contributes to hepatic steatosis, triglyceride clearance, and regulation of body fat mass," Journal of Biological Chemistry, vol. 278, no. 36, pp. 34268-34276, 2003.

[94] P. D. Denechaud, P. Bossard, J. M. Lobaccaro et al., "LXR stimulates ChREBP expression but glucose is required its post-traductional activation," Diabetes, vol. 56, p. A39, 2007.

[95] N. Guillén, M. A. Navarro, C. Arnal et al., "Microarray analysis of hepatic gene expression identifies new genes involved in steatotic liver," Physiological Genomics, vol. 37, no. 3, pp. 187-198, 2009.

[96] X. Lin, J. J. Loor, and J. H. Herbein, “Trans10,cis12-18:2 is a more potent inhibitor of de novo fatty acid synthesis and desaturation than cis9, trans11-18:2 in the mammary gland of lactating mice," Journal of Nutrition, vol. 134, no. 6, pp. 1362-1368, 2004.

[97] D. M. Stringer, P. Zahradka, V. C. DeClercq et al., "Modulation of lipid droplet size and lipid droplet proteins by trans10,cis-12 conjugated linoleic acid parallels improvements in hepatic steatosis in obese, insulin-resistant rats," Biochimica et Biophysica Acta, vol. 1801, no. 12, pp. 1375-1385, 2010.

[98] G. Musso, R. Gambino, G. Pacini, F. De Michieli, and M. Cassader, "Prolonged saturated fat-induced, glucosedependent insulinotropic polypeptide elevation is associated with adipokine imbalance and liver injury in nonalcoholic steatohepatitis: dysregulated enteroadipocyte axis as a novel feature of fatty liver," American Journal of Clinical Nutrition, vol. 89, no. 2, pp. 558-567, 2009.

[99] H. Doege, R. A. Baillie, A. M. Ortegon et al., "Targeted deletion of FATP5 reveals multiple functions in liver metabolism: alterations in hepatic lipid homeostasis," Gastroenterology, vol. 130, no. 4, pp. 1245-1258, 2006.

[100] S. L. Zhou, F. X. Ge, C. G. Hu et al., "Increased insulinand leptin-regulated hepatocellular fatty acid uptake plays a major role in the pathogenesis of hepatic steatosis in mouse models with intact leptin signaling, but not in those lacking leptin $(\mathrm{ob} / \mathrm{ob})$ or the leptin receptor $(\mathrm{db} / \mathrm{db})$, , Hepatology, vol. 48, no. 4, p. 1161, 2008.

[101] M. A. Belury, S. Y. Moya-Camarena, M. Lu, L. Shi, L. M. Leesnitzer, and S. G. Blanchard, "Conjugated linoleic acid is an activator and ligand for peroxisome proliferator-activated receptor-gamma (PPAR $\gamma)$," Nutrition Research, vol. 22, no. 7, pp. 817-824, 2002.

[102] P. Degrace, B. Moindrot, I. Mohamed et al., "Upregulation of liver VLDL receptor and FAT/CD36 expression in LDLR -/- 
apoB100/100 mice fed trans-10,cis-12 conjugated linoleic acid," Journal of Lipid Research, vol. 47, no. 12, pp. 26472655, 2006.

[103] A. Nagayoshi, N. Matsuki, H. Saito et al., "Defect in assembly process of very-low-density lipoprotein in suncus liver: an animal model of fatty liver," Journal of Biochemistry, vol. 117, no. 4, pp. 787-793, 1995.

[104] Y. Lin, E. Schuurbiers, S. Van Der Veen, and E. A. M. De Deckere, "Conjugated linoleic acid isomers have differential effects on triglyceride secretion in Hep G2 cells," Biochimica et Biophysica Acta, vol. 1533, no. 1, pp. 38-46, 2001.

[105] J. K. Reddy and T. Hashimoto, "Peroxisomal $\beta$-oxidation and peroxisome proliferator - Activated receptor $\alpha$ : an adaptive metabolic system," Annual Review of Nutrition, vol. 21, pp. 193-230, 2001.

[106] M. Javadi, A. C. Beynen, R. Hovenier et al., "Prolonged feeding of mice with conjugated linoleic acid increases hepatic fatty acid synthesis relative to oxidation," Journal of Nutritional Biochemistry, vol. 15, no. 11, pp. 680-687, 2004.

[107] J. M. Chardigny, O. Hasselwander, M. Genty, K. Kraemer, A. Ptock, and J. L. Sébédio, "Effect of conjugated FA on feed intake, body composition, and liver FA in mice," Lipids, vol. 38, no. 9, pp. 895-902, 2003.

[108] D. S. Kelley, G. L. Bartolini, J. M. Warren, V. A. Simon, B. E. Mackey, and K. L. Erickson, "Contrasting effects of t10,c12and c9,t11-conjugated linoleic acid isomers on the fatty acid profiles of mouse liver lipids," Lipids, vol. 39, no. 2, pp. 135141, 2004.

[109] D. S. Kelley, G. L. Bartolini, J. W. Newman, M. Vemuri, and B. E. Mackey, "Fatty acid composition of liver, adipose tissue, spleen, and heart of mice fed diets containing t10, c12-, and c9, t11-conjugated linoleic acid," Prostaglandins Leukotrienes and Essential Fatty Acids, vol. 74, no. 5, pp. 331-338, 2006.

[110] S. V. Martins, P. A. Lopes, S. P. Alves et al., "Dietary conjugated linoleic acid isomers change the unsaturation degree of hepatic fatty acids in neutral lipids but not in polar lipids," Nutrition Research, vol. 31, no. 3, pp. 246-254, 2011.

[111] J. L. Sébédio, E. Angioni, J. M. Chardigny, S. Grégoire, P. Juanéda, and O. Berdeaux, "The effect of conjugated linoleic acid isomers on fatty acid profiles of liver and adipose tissues and their conversion to isomers of 16:2 and 18:3 conjugated fatty acids in rats," Lipids, vol. 36, no. 6, pp. 575-582, 2001.

[112] P. Puri, R. A. Baillie, M. M. Wiest et al., "A lipidomic analysis of nonalcoholic fatty liver disease," Hepatology, vol. 46, no. 4, pp. 1081-1090, 2007.

[113] D. Wang, Y. Wei, and M. J. Pagliassotti, "Saturated fatty acids promote endoplasmic reticulum stress and liver injury in rats with hepatic steatosis," Endocrinology, vol. 147, no. 2, pp. 943-951, 2006.

[114] K. Eder, N. Slomma, and K. Becker, “Trans-10,cis-12 conjugated linoleic acid suppresses the desaturation of linoleic and $\alpha$-linolenic acids in HepG2 cells," Journal of Nutrition, vol. 132, no. 6, pp. 1115-1121, 2002.

[115] X. Lin, J. Bo, S. A. M. Oliver et al., "Dietary conjugated linoleic acid alters long chain polyunsaturated fatty acid metabolism in brain and liver of neonatal pigs," The Journal of Nutritional Biochemistry. In press.

[116] M. Sugano, A. Tsujita, M. Yamasaki, M. Noguchi, and K. Yamada, "Conjugated linoleic acid modulates tissue levels of chemical mediators and immunoglobulins in rats," Lipids, vol. 33, no. 5, pp. 521-527, 1998.

[117] O. Y. Lukivskaya, A. A. Maskevich, and V. U. Buko, "Effect of ursodeoxycholic acid on prostaglandin metabolism and microsomal membranes in alcoholic fatty liver," Alcohol, vol. 25, no. 2, pp. 99-105, 2001.

[118] A. M. El-Badry, R. Graf, and P. A. Clavien, "Omega 3 - Omega 6: what is right for the liver?" Journal of Hepatology, vol. 47, no. 5, pp. 718-725, 2007.

[119] Y. Li and B. A. Watkins, "Conjugated linoleic acids alter bone fatty acid composition and reduce ex vivo prostaglandin E2 biosynthesis in rats fed n-6 or n-3 fatty acids," Lipids, vol. 33, no. 4, pp. 417-425, 1998.

[120] K. Eder, N. Slomma, K. Becker, and C. Brandsch, "Effect of linseed oil supplementation on concentrations of (n-3) polyunsaturated fatty acids in liver phospholipids of rats fed diets containing either an oil rich in conjugated linoleic acids, sunflower oil or high-oleic acid sunflower oil," Journal of Animal Physiology and Animal Nutrition, vol. 89, no. 1-2, pp. 45-54, 2005.

[121] S. Banni, A. Petroni, M. Blasevich et al., "Conjugated linoleic acids (CLA) as precursors of a distinct family of PUFA," Lipids, vol. 39, no. 11, pp. 1143-1146, 2004.

[122] J. M. Brown and M. K. McIntosh, "Conjugated linoleic acid in humans: regulation of adiposity and insulin sensitivity," Journal of Nutrition, vol. 133, no. 10, pp. 3041-3046, 2003.

[123] K. Kang, M. Miyazaki, J. M. Ntambi, and M. W. Pariza, "Evidence that the anti-obesity effect of conjugated linoleic acid is independent of effects on stearoyl-CoA desaturase1 expression and enzyme activity," Biochemical and Biophysical Research Communications, vol. 315, no. 3, pp. 532-537, 2004.

[124] Y. Park, J. M. Storkson, J. M. Ntambi, M. E. Cook, C. J. Sih, and M. W. Pariza, "Inhibition of hepatic stearoyl-CoA desaturase activity by trans-10,cis- 12 conjugated linoleic acid and its derivatives," Biochimica et Biophysica Acta, vol. 1486, no. 2-3, pp. 285-292, 2000.

[125] J. M. Ntambi, M. Miyazaki, J. P. Stoehr et al., "Loss of stearoyl-CoA desaturase-1 function protects mice against adiposity," Proceedings of the National Academy of Sciences of the United States of America, vol. 99, no. 17, pp. 11482-11486, 2002.

[126] M. L. E. MacDonald, R. R. Singaraja, N. Bissada et al., "Absence of stearoyl-CoA desaturase-1 ameliorates features of the metabolic syndrome in LDLR-deficient mice," Journal of Lipid Research, vol. 49, no. 1, pp. 217-229, 2008.

[127] M. Miyazaki, M. T. Flowers, H. Sampath et al., "Hepatic stearoyl-CoA desaturase-1 deficiency protects mice from carbohydrate-induced adiposity and hepatic steatosis," Cell Metabolism, vol. 6, no. 6, pp. 484-496, 2007.

[128] R. Gutiérrez-Juárez, A. Pocai, C. Mulas et al., "Critical role of stearoyl-CoA desaturase - 1 (SCD1) in the onset of diet-induced hepatic insulin resistance," Journal of Clinical Investigation, vol. 116, no. 6, pp. 1686-1695, 2006.

[129] G. Jiang, Z. Li, F. Liu et al., "Prevention of obesity in mice by antisense oligonucleotide inhibitors of stearoyl-CoA desaturase-1," Journal of Clinical Investigation, vol. 115, no. 4, pp. 1030-1038, 2005.

[130] M. T. Flowers and J. M. Ntambi, "Role of stearoyl-coenzyme A desaturase in regulating lipid metabolism," Current Opinion in Lipidology, vol. 19, no. 3, pp. 248-256, 2008.

[131] R. L. House, J. P. Cassady, E. J. Eisen et al., "Functional genomic characterization of delipidation elicited by trans-10, cis-12-conjugated linoleic acid (t10c12-CLA) in a polygenic obese line of mice," Physiological Genomics, vol. 21, pp. 351361, 2005.

[132] C. M. Reynolds and H. M. Roche, "Conjugated linoleic acid and inflammatory cell signalling," Prostaglandins 
Leukotrienes and Essential Fatty Acids, vol. 82, no. 4-6, pp. 199-204, 2010.

[133] J. J. Senn, P. J. Klover, I. A. Nowak et al., "Suppressor of cytokine signaling-3 (SOCS-3), a potential mediator of interleukin-6-dependent insulin resistance in hepatocytes," Journal of Biological Chemistry, vol. 278, no. 16, pp. 1374013746, 2003.

[134] P. A. Kern, G. B. Di Gregorio, T. Lu, N. Rassouli, and G. Ranganathan, "Adiponectin expression from human adipose tissue: relation to obesity, insulin resistance, and tumor necrosis factor- $\alpha$ expression," Diabetes, vol. 52 , no. 7, pp. 1779-1785, 2003.

[135] N. Tsuboyama-Kasaoka, H. Miyazaki, S. Kasaoka, and O. Ezaki, "Increasing the amount of fat in a conjugated linoleic acid-supplemented diet reduces lipodystrophy in mice," Journal of Nutrition, vol. 133, no. 6, pp. 1793-1799, 2003.

[136] K. Nagao, N. Inoue, Y. Ujino et al., "Effect of leptin infusion on insulin sensitivity and lipid metabolism in diet-induced lipodystrophy model mice," Lipids in Health and Disease, vol. 7, article 8, 2008.

[137] M. Stout, L. Li, and M. Belury, "Hepatic steatosis by dietaryconjugated linoleic acid is accompanied by accumulation of diacylglycerol and increased membrane-associated protein kinase C $\varepsilon$ in mice," Molecular Nutrition and Food Research, vol. 55, no. 7, pp. 1010-1017, 2011.

[138] P. C. LaRosa, J. J. M. Riethoven, H. Chen et al., "Trans-10, cis-12 conjugated linoleic acid activates the integrated stress response pathway in adipocytes," Physiological Genomics, vol. 31, no. 3, pp. 544-553, 2007.

[139] H. Poirier, I. Niot, L. Clément, M. Guerre-Millo, and P. Besnard, "Development of conjugated linoleic acid (CLA)mediated lipoatrophic syndrome in the mouse," Biochimie, vol. 87, no. 1, pp. 73-79, 2005.

[140] D. Oikawa, S. Tsuyama, Y. Akimoto, Y. Mizobe, and M. Furuse, "Arachidonic acid prevents fatty liver induced by conjugated linoleic acid in mice," British Journal of Nutrition, vol. 101, no. 10, pp. 1558-1563, 2009.

[141] A. Ferramosca, V. Savy, L. Conte, and V. Zara, "Dietary combination of conjugated linoleic acid (CLA) and pine nut oil prevents CLA-induced fatty liver in mice," Journal of Agricultural and Food Chemistry, vol. 56, no. 17, pp. 81488158, 2008.

[142] M. Vemuri, D. S. Kelley, and G. Bartolini, "Decosahexaenoic acid (DHA) but not eicosapentaenoic acid (EPA) reverses trans-10, cis-12-conjugated linoleic acid (t10, c12-CLA) induced insulin resistance in mice," Faseb Journal, vol. 21, no. 5, p. A113, 2007.

[143] H. M. Roche, E. Noone, C. Sewter et al., "Isomerdependent metabolic effects of conjugated linoleic acid: insights from molecular markers sterol regulatory elementbinding protein-1c and LXR $\alpha$," Diabetes, vol. 51, no. 7, pp. 2037-2044, 2002.

[144] M. K. Mater, A. P. Thelen, and D. B. Jump, "Arachidonic acid and PGE2 regulation of hepatic lipogenic gene expression," Journal of Lipid Research, vol. 40, no. 6, pp. 1045-1052, 1999.

[145] Y. Choi, Y. C. Kim, Y. B. Han, Y. Park, M. W. Pariza, and J. M. Ntambi, "The trans-10,cis-12 isomer of conjugated linoleic acid downregulates stearoyl-CoA desaturase 1 gene expression in 3T3-L1 Adipocytes," Journal of Nutrition, vol. 130, no. 8, pp. 1920-1924, 2000.

[146] J. S. Choi, I. U. Koh, M. H. Jung, and J. Song, "Effects of three different conjugated linoleic acid preparations on insulin signalling, fat oxidation and mitochondrial function in rats fed a high-fat diet," British Journal of Nutrition, vol. 98, no. 2, pp. 264-275, 2007.

[147] B. De Roos, G. Rucklidge, M. Reid et al., "Divergent mechanisms of cis9, trans11-and trans10, cis12-conjugated linoleic acid affecting insulin resistance and inflammation in apolipoprotein E knockout mice: a proteomics approach," FASEB Journal, vol. 19, no. 12, pp. 1746-1748, 2005. 


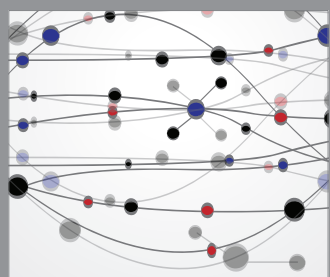

The Scientific World Journal
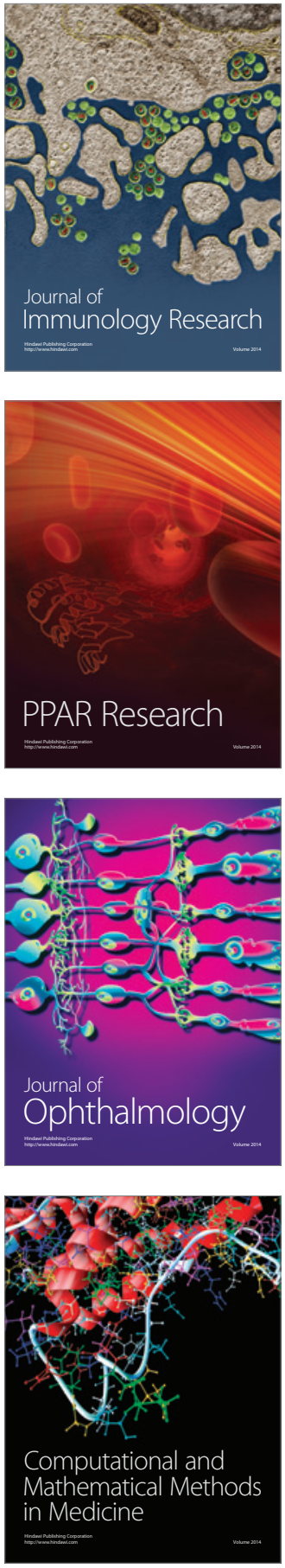

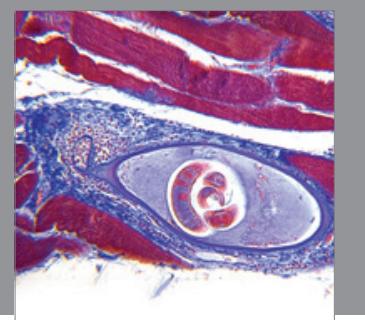

Gastroenterology

Research and Practice
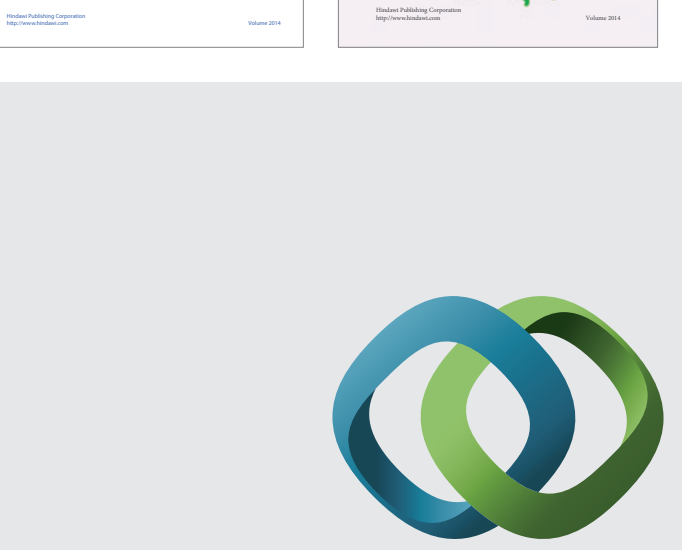

\section{Hindawi}

Submit your manuscripts at

http://www.hindawi.com
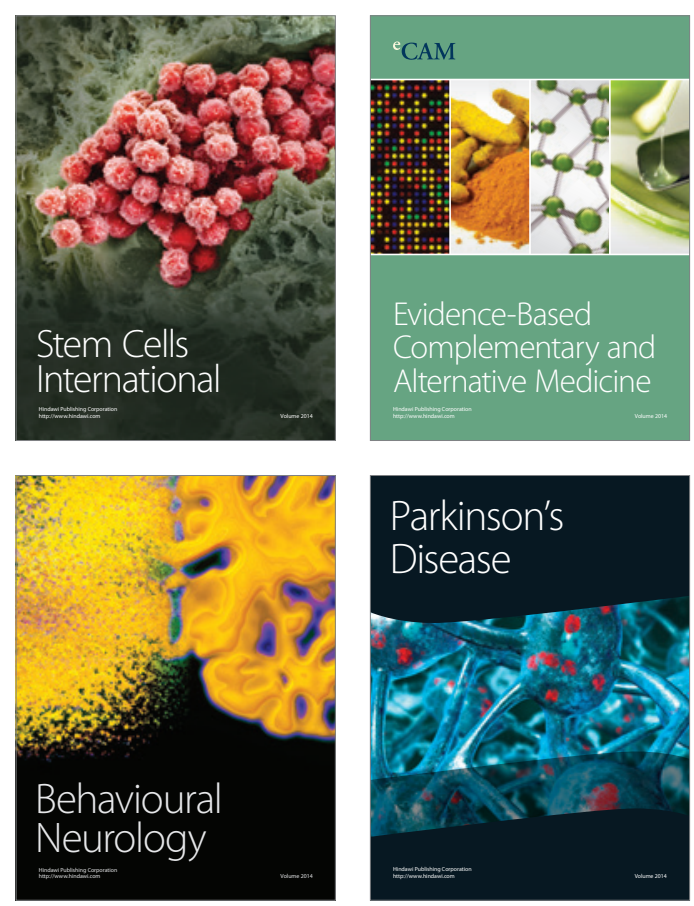

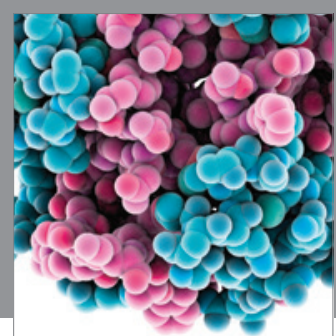

Journal of
Diabetes Research

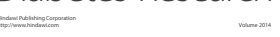

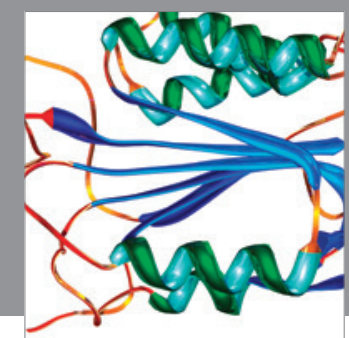

Disease Markers
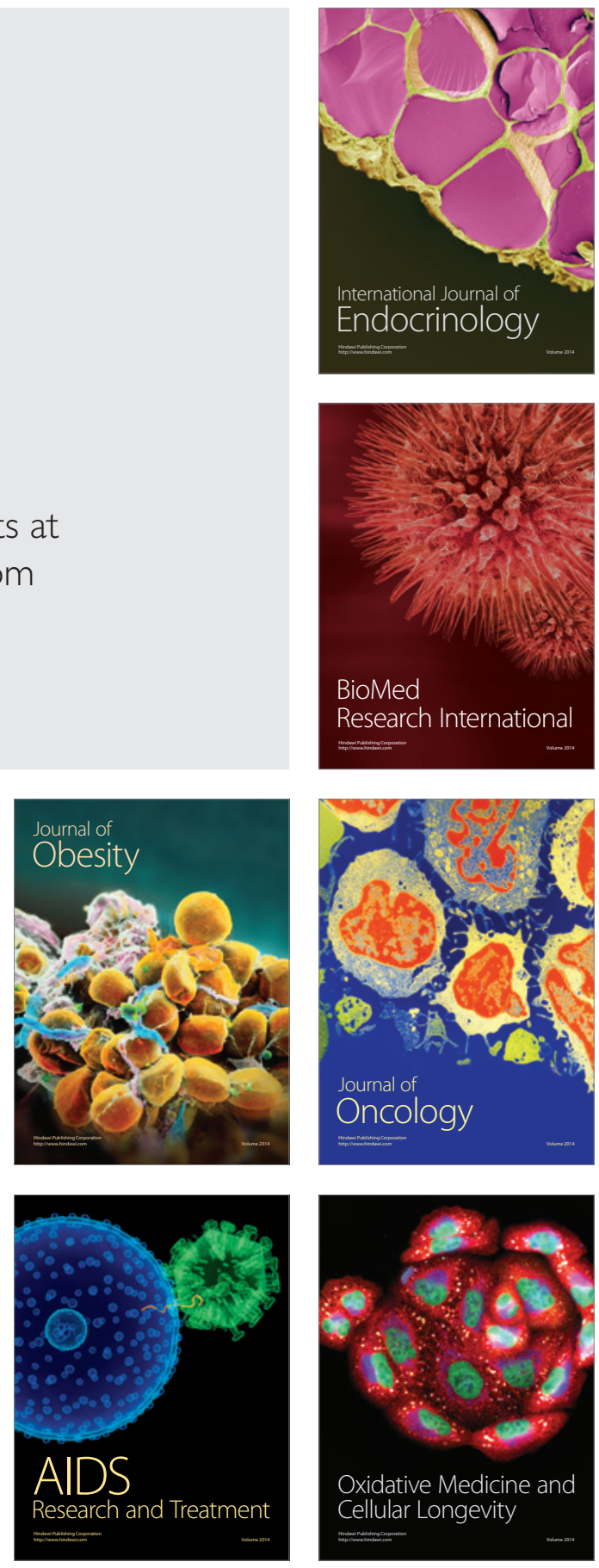